\title{
A STUDY OF 100 CASES OF ARRYTHMIAS IN FIRST WEEK OF ACUTE MYOCARDIAL INFARCTION
}

KEY WORDS: Arrhythmia, Acute myocardial infarction, ECG ,VPC , Heart Block , V. tachycardia

\section{Dr. Harita M. Patel*}

Department of General Medicine, 3rd year resident of General Medicine, Gujarat Adani Institute of Medical Sciences - Bhuj, Gujarat - India. *Corresponding Author

Department of General Medicine, 2nd year resident of General Medicine, Gujarat Adani Institute of Medical Sciences - Bhuj, Gujarat - India.

Dr. Hitarth Joshi

BACKGROUND: Incidence of Arrhythmia in first week of Acute myocardial infarction.

AIM : To study the incidence of arrhythmias in the first week of Acute Myocardial Infarction (AMI) with respect to type of arrhythmia, age distribution, sex and location of infarction, various risk factors in a patient population from western India and to evaluate its prognostic value and relation of complications with incidence of arrhythmias. METHOD : Hundred cases of AMI with arrhythmia admitted in ICCU of G K GENERAL HOSPITAL - GAIMS , BHUJ were taken in the study.

RESULT:

- Among 100 cases, maximum incidence (40\%) was found in 6th decade. Incidence of arrhythmias was higher in males $(81 \%)$ than females (19\%). Anterior wall infarcts $(61 \%)$ were more common than inferior wall (36\%). Ventricular Premature Contraction (VPC) was the commonest arrhythmia is anterior wall MI (45.9\%) and in inferior wall MI (19.4\%).

\section{CONCLUSION :}

- Hence, in one of the largest study of this kind in a patient population of Western India, we established VPC's as the most common arrhythmia in AMI patients. Older patients (sixth decade) and males are affected more commonly. Ventricular tachycardia is more fatal in acute inferior wall MI.

\section{INTRODUCTION:}

- Despite impressive strides in diagnosis and management, over last three decades Acute Myocardial Infarction continues to be a major public health problem in developing and developed countries.. The incidence of coronary artery disease has reported to be on an increase in India and occur almost a decade earlier in life as compared to the people of western world, as it has been found that Indians in particular and South Asians in general are genetically more susceptible to Atherosclerotic coronary artery disease.

- Cardiac arrhythmias directly and indirectly affect the morbidity and mortality of the patient with myocardial infarction and they are also related to in hospital and late mortality ${ }^{1}$.

- During the past few years, increasing emphasis is being placed on early pathophysiological events that occur in Acute Myocardial Infarction. Thrombolytic therapy and advent of CABG and PTCA have made it possible to reperfuse the obstructed vessels within a short time and to salvage the jeopardized myocardium and has thus, revolutionized the treatment of Acute Myocardial Infarction. Significant salvage of myocardium and improved survival results only when these myocardial sparing interventions are instituted within hours of onset of symptoms.

- This study includes 100 patients admitted in Intensive Coronary Care Unit having Acute Myocardial Infarction with Arrhythmias within first week of hospitalization and especially the first 24 hours. This study was undertaken to evaluate Incidence profile of arrhythmias and ultimately mortality and morbidity of various arrhythmias in Acute Myocardial Infarction

\section{AIMS AND OBJECTIVES:}

- To Study the incidence, influence of location of infarction, the prognostic value of various cardiac arrhythmias and the relation of associated complications on incidence of cardiac arrhythmias in Acute Myocardial Infarction.

\section{MATERIALS AND METHODS:}

After obtaining approval from institutional ethical committee and written informed patient consent.
- It is a prospective clinical study consisting of 100 consecutive patients admitted in ICCU of G K GENERAL HOSPITAL-GAIMS,BHUJ with following criteria.

\section{INCLUSION CRITERIA:-}

- Age:25 to 80Years

- Diagnosed as Acute ST elevation MI

- Reached to ICCU within window period of $12 \mathrm{hrs}$

- Only those who are treated with fibrinolytic agents on admission

- Patients who developed arrhythmias within 1 week of acute MI

- Those who admitted in the hospital for 1 week so proper follow up could be possible

- Patients who have given Informed consent and who are willing to participate in this

\section{EXCLUSION CRITERIA:-}

- Age $<25$ or $>80$ years

- NonST elevation MI

- Presented to emergency department out of window period of thrombolysis

- Patients who didn't developed arrhythmias within 1 week or who had arrhythmias after 1 week of admission

- Those who have contraindication of Thrombolysis (CVAHemorrhagic or Ischemic, Recent major surgery or facial trauma, Head injury, CNS malignancy, Bleeding disorders, INR $>1.8$ ) are excluded

- Those patients who were not willing for thrombolysis

\section{METHODOLOGY}

- Clinical history was recorded including age, sex, occupation and signs and symptoms of myocardial infarction like chest pain, palpitation, perspiration, nausea, vomiting and breathlessness along with significant past, personal and family history.

- The necessary investigation carried out included blood sugar, serum creatinine, Serum cholesterol , Troponin-I were done.

- 12 lead ECG was taken immediately on admission and once daily and as when required.

- Diagnosis of acute myocardial infarction was made when corresponding leads showed fresh appearance of ' $Q$ ' 
wave of more than $0.04 \mathrm{sec}$ duration and having depth of more than $25 \%$ of $\mathrm{R}$ wave height with ST segment deviation and $\mathrm{T}$ wave changes.

- Anterior wall MI included such changes in V1 to V6

- Inferior wall MI included changes in leads II, III and aVf

- Anterior + Inferior wall MI included changes in leads II, III and $\mathrm{aVf}$ and Vl toV6

- Extensive anterior wall MI included changes in lead I, aVl andVI to V6

- Antero septal MI included changes in leadVI toV4

- Inferior and right ventricular infarction included changes in leads II;III, aVf and RVl to Rv6

- Various types of arrhythmias were diagnosed by ECG and on cardiac monitor. Patient was examined daily and/or as frequently as needed by noting pulse, blood pressure and signs of any complication. Careful search was made daily to find out any rhythm disorder and if any irregularity was detected, it was recorded immediately on electrocardiogram.

- Two-dimensional echocardiography with Doppler echocardiography was done within first five days of onset of symptoms in some patients

\section{RESULTS}

Table 1 Age distribution in acute MI with arrhythmia

\begin{tabular}{|l|l|l|}
\hline Age in years & No. of cases & Percentage \% \\
\hline 21 to 30 & 1 & 1 \\
\hline 31 to 40 & 5 & 5 \\
\hline 41 to 50 & 25 & 25 \\
\hline 51 to 60 & 40 & 40 \\
\hline 61 to 70 & 22 & 22 \\
\hline 71 to 80 & 7 & 7 \\
\hline More than 81 & 0 & - \\
\hline
\end{tabular}

- Among 100 cases studied, maximum incidence was during the sixth decade( $40 \%)$. The youngest was 28 years, while the oldest was 75 years.(Table- 1 )

- AMI with arrhythmia is more common in males (81\%) than females (19\%).

- The anterior wall infarction with arrhythmia (61\%) was more common than the inferior wall infarction (36\%) and combined anterior and inferior wall infarction was observed in only $3 \%$ of cases.

TABLE-2: Incidence of Anatomical Sites of Myocardial Infarction with Arrhythmia

- Complications like Left ventricular dysfunction and cardiogenic shock are more common with anterior wall infarction combined with inferior wall infarction (100\%) than inferior wall

\begin{tabular}{|l|l|l|}
\hline $\begin{array}{l}\text { Anatomical sites of } \\
\text { Myocardial infarction }\end{array}$ & No. of cases & Percentage \% \\
\hline Anterior wall & 61 & 61 \\
\hline Inferior wall & 36 & 36 \\
\hline $\begin{array}{l}\text { Anterior + Inferior } \\
\text { wall }\end{array}$ & 03 & 03 \\
\hline
\end{tabular}

TABLE-3: Incidence of Various Complications in Relation to Anatomical Site

\begin{tabular}{|l|l|l|l|l|}
\hline Complication & $\begin{array}{l}\text { Anterior } \\
\text { wall }\end{array}$ & $\begin{array}{l}\text { Inferior } \\
\text { wall }\end{array}$ & $\begin{array}{l}\text { Anterior + } \\
\text { Inferior } \\
\text { wall }\end{array}$ & Total \\
\hline $\begin{array}{l}\text { Left } \\
\text { ventricular } \\
\text { dysfunction }\end{array}$ & $\begin{array}{l}19 \\
(31.14 \%)\end{array}$ & $\begin{array}{l}05 \\
(13.88 \%)\end{array}$ & $03(50 \%)$ & $27(27 \%)$ \\
\hline $\begin{array}{l}\text { Cardiogenic } \\
\text { shock }\end{array}$ & $\begin{array}{l}08 \\
(13.11 \%)\end{array}$ & $\begin{array}{l}03 \\
(8.33 \%)\end{array}$ & $03(50 \%)$ & $14(14 \%)$ \\
\hline total & $\begin{array}{l}27 \\
(44.25 \%)\end{array}$ & $\begin{array}{l}08 \\
(22.22 \%)\end{array}$ & $06(100 \%)$ & $41(41 \%)$ \\
\hline
\end{tabular}

TABLE- 4: Incidence of Various Arrhythmias in Acute MI

- In Acute MI most common arrhythmia are VPC's (33\%), followed by Atrial fibrillation (13\%), Complete heart block (11\%) andVentricular tachycardia (11\%)

\begin{tabular}{|l|l|l|l|l|l|}
\hline No & Arrythmias & $\begin{array}{l}\text { No of } \\
\text { cases }\end{array}$ & $\begin{array}{l}\text { Percent } \\
\text { age \% }\end{array}$ & $\begin{array}{l}\text { No of } \\
\text { deaths }\end{array}$ & $\begin{array}{l}\text { Percent } \\
\text { age \% }\end{array}$ \\
\hline 1 & $\begin{array}{l}\text { Ventricularprema } \\
\text { ture beats }\end{array}$ & 33 & 33 & 0 & - \\
\hline 2 & $\begin{array}{l}\text { Atrial premature } \\
\text { beats }\end{array}$ & 07 & 07 & 0 & - \\
\hline 3 & Atrial fibrillation & 13 & 13 & 02 & 15.31 \\
\hline 4 & $\begin{array}{l}\text { Ventriculartachyc } \\
\text { ardia }\end{array}$ & 11 & 11 & 07 & 63.63 \\
\hline 5 & $\begin{array}{l}\text { Second degree } \\
\text { AV block type 1 }\end{array}$ & 03 & 03 & 0 & - \\
\hline 6 & $\begin{array}{l}\text { Second degree } \\
\text { AV block type 2 }\end{array}$ & 05 & 05 & 02 & 40 \\
\hline 7 & $\begin{array}{l}\text { First degree AV } \\
\text { block }\end{array}$ & 04 & 04 & 0 & - \\
\hline 8 & Bifascicular block & 03 & 03 & 0 & - \\
\hline 9 & $\begin{array}{l}\text { RBBB } \\
\text { LBBB }\end{array}$ & 03 & 03 & 03 & 100 \\
\hline 10 & $\begin{array}{l}\text { Complete heart } \\
\text { block }\end{array}$ & 11 & 11 & 05 & 45.45 \\
\hline 12 & $\begin{array}{l}\text { Ventricularfibrilla } \\
\text { tion }\end{array}$ & 02 & 02 & 02 & 100 \\
\hline 13 & $\begin{array}{l}\text { Ventricularstands } \\
\text { till }\end{array}$ & 01 & 01 & 01 & 100 \\
\hline & Ang & 02 & 50 \\
\hline
\end{tabular}

- Among the arrhythmias in Anterior wall infarction VPC's are the most common

- Most common arrhythmia in Inferior wall is Ventricular premature beats (19.44\%) followed by Second degree AV block type 2

- Higher mortality was in anterior wall (27.8\%) than inferior wall $(13.9 \%)$, while highest in combined anterior and inferior wall infarction (100\%).

- Only three cases of Ventricular fibrillation and Ventricular standstill were reported and mortality was $100 \%{ }^{5}$

\section{DISCUSSION}

- Maximum incidence was found in sixth decade in present study consistent with Prabhu et al, Rajgopalan et al,studies. The increased incidence of myocardial infarction seen in fifth and sixth decade was probably due to increased prevalence of atherosclerosis and CAD in this decade. As the age increases, the vessels become stiffer, causing rise in systolic blood pressure and left ventricular hypertrophy which is an independent risk factor for IHD. It was found that excess CAD mortality attributable to hypercholesterolemia increased more than five times with age in a study done in elderly between 60 to 79 years of age in Observational Kaiser Permanente coronary heart disease in elderly ${ }^{8}$

- In our study anterior wall infarction was observed in $61 \%$, Inferior wall infarction in $36 \%$ and combined in $3 \%$ of cases that is consistent with result of Imperial.

- VPC's in our study (33\%) is comparable with Annamalai and Kasirajan (28.5\%) and Hurcaitz (30\%).While APC's in our study $(7 \%)$ is comparable with Pick $(7.25 \%)$, Master $(5 \%)$ and Hurcaitz $(6 \%)$. Due to imbalance in autonomic nervous system and electrolytes arising because of myocardial infarction, the commonest abnormality seen is abnormal and enhanced automaticity leading to premature contraction and thus, they are found to be the most common arrhythmia. It is possible that partial depolarization and failure to reach the maximal diastolic potential can induce automatic discharge in most of the cardiac fibres. ${ }^{8}$

- In our study incidence of Atrial fibrillation is $13 \%$, which is consistent with Julian (16\%), Broan (10\%) and Annalmalai and Kasirajan (14\%). Out of the supraventricular arrhythmia, atrial fibrillation in relation to myocardial infarction was found to be the most common arrhythmia with no specific predilection for any wall of infarction. Atrial fibrillation was associated with high ventricular rate 
and left ventricular failure. ${ }^{10}$

- Incidence of Ventricular tachycardia (11\%) in present study is well comparable with Desanctis et al (10\%), Broan (11.1\%) and Annamalai and Kasirajan (9.5\%), The incidence of ventricular tachycardia was more common in anterior wall infarction ( 9 cases) than in inferior wall infarction (2 cases) as it might be related also to amount of myocardium damaged. The urgent need of revascularization in form of Primary Angioplasty and CABG for treating ventricular tachycardia is not available in our set up which might have caused higher mortality in patients with ventricular tachycardia ${ }^{8}$

- In the present study incidence of Ventricular fibrillation $(2 \%)$ is comparable with Lawrence and Annamalai. The occurrence of ventricular fibrillation supports the Moe's multiple wavelet hypothesis theory, according to which when there is a non-uniformity of recovery of ventricles, fibrillation can occur primarily by re-entry extension of circulating wave fronts. In present study there was no primary ventricular fibrillation. All the ventricular fibrillations that occurred were secondary ventricular fibrillation i.e. the patients had both anterior and inferior wall infarction and large mass of infarcted myocardium and left ventricular failure and cardiogenic shock leading to ventricular fibrillation.

- Incidence of $\mathrm{A}-\mathrm{V}$ block is more frequent in patient with Inferior wall infarction (47.21\%) than with Anterior wall infarction $(8.20 \%)$ and is comparable with finding of Sulton et al. ${ }^{3}$

- Incidence of Bundle branch block in present study is (7\%) is comparable with Hunt et al, Bauer et al and Julian et al. ${ }^{4,9}$

\section{CONCLUSION:}

- We can conclude that Acute MI with arrhythmia was most common in Sixth decade (40\%) and male to female ratio is $4.26: 1$. Incidence of arrhythmia with anterior wall infarction was more common (61\%) than with Inferior wall infarction (36\%). Most common arrhythmia observed was premature beats and VPC's were more common (33\%). Conduction disturbances were common in Inferior wall infarction (55.54\%). Atrial fibrillation (13\%), Ventricular tachycardia $(10 \%)$ are more common with anterior wall infarction. Complete heart block (11\%) are more common with Inferior wall infarction. Arrhythmia carrying very high mortality includes Ventricular standstill $(100 \%)$, Ventricular fibrillation (100\%), Ventricular tachycardia (63\%) and Bundle branch block (71.11\%).

\section{REFERENCES}

1. AL ANNAMALAI, N. KASIRAJAN : Arrhythmias in Myocardial infarction. Indian Heart journal,july 1966,247-254

2. BILBAO F.J., ZABALIZA T.E., VILANOVA J.R. ET AL. : A-V block in posterior acute myocardial infarction. A clinical-pathologic correlation. Circulation. 75:733,1987

3. BRIG. H.B.LAL AND R.K. CAROLI : Acute myocardial infarction in higher income group patients. Some clinical, electrocardiographic and biochemical observations, Indian Heart Journal January, 1967, 12-28

4. BRILAKI E.S. AND WRIGHT R.S. : Prognostic implication of Bundle Branch Block complicating myocardial infarction. American Journal of Cardiology. 2001, Aug-188 (3): 205-209

5. CAMPBELL R.W.F., MURRY A, JULIAN P G :Ventricular arrhythmias in first 12 hours of Acute myocardial infarction. Natural History study. British Heart Journal 46:361,1981.

6. CAMPBELL R.W.F., JULIAND AND BRAUNWALD ET AL. : Management of Acute Myocardial Infarction. British Heart Journal 46:360,1981.

7. CORR P.B. AND CILLIS R.A. : Autonomic neural influence on the dysrhythmias resulting from myocardial infarction. Circulation Res. 43:1, 1978.

8. BRAUNWALD 10 TH EDITION, 2015. : Heart disease, A Text Book of CardioVascular medicine

9. DAVID HUNT AND GRAEMA SOLOMAN : Bundle Branch Block in Acute Myocardial Infarction.

10. British Medical Journal, January 1969. 1:85-86

11. D.E. JEWITT, R. BALCO, E.B.RAFFEY AND S. ORAM. : Incidence and management of Supra

12. ventricular arrhythmias after Acute Myocardial Infarction. The Lancet. Oct. 1967.734-740

13. ECOSTEGUY C.C., CARVALLO-MDE-A ET AL : Intraventricular conduction disturbance and $A-V$ block during the current era of thrombolytic therapy in acute myocardial infarction. Arq. Bras Cardiol 2001, April: 76(4) 291-296.

14. El-SHERIF N, MYERBURG R. J, SCHERLAG B. J ET AL : Electrocardiographic antecedents of primary ventricular fibrillation. Value of $\mathrm{R}$ on $\mathrm{T}$ phenomenon in myocardial infarction. British Heart Journal 38:415,1976.
15. GOLDBERG R.J.,YARZABSKI J, LESSAR D ET AL : Incidence of Atrial fibrillation complicating

16. myocardial infarction in modern era. American Heart Journal 2002 March, 143 (3):519-27.

17. GRANER L.E., GERSHNER B.J, ORLANDO M.M. ET AL : Bradycardia and its complication in pre-

18. hospital phase of acute myocardial infarction. American Journal of Cardiology, 32:607, 1973.

19. LAWREWES E., MELTRER AND J.B. KITCHELL : The incidence of arrhythmia associated with

20. Acute Myocardial Infarction. Prog. In Cardiology.Volume 9,No. 1 (July) 1966

21. JULIAN D. G,VALENTINE P.A. AND MULLER G. G:Disturbances of rate, rhythm and conduction in Acute myocardial infarction; A prospective study of 100 consecutive unselected patients with the aid of electrocardiographic Monitor.American Journal of Medicine. 37:915-927,1964. 